\title{
Home range size and breeding dispersal of a common buzzard (Buteo buteo)
}

\author{
Vel'kost' domovského okrsku a hniezdna disperzia myšiaka hôrneho (Buteo buteo)
}

\author{
Ülo VÄLI
}

\begin{abstract}
Telemetric studies have provided ample information on threatened raptors, but still little is known about space use and dispersal of common species. Here I describe the home range and breeding dispersal of a GPS-tracked adult male common buzzard, studied in south-eastern Estonia in 2014-16. This buzzard's home range covered $8.3 \mathrm{~km}^{2}$ (kernel 95\% estimate) with the core range being $2.1 \mathrm{~km}^{2}$ (kernel 50\%). The home range increased in the course of the breeding season but decreased again before migration. Surprisingly, the nests in the two successive breeding years were located in the opposite margins of the home range, $1.7 \mathrm{~km}$ from each other.
\end{abstract}

\begin{abstract}
Abstrakt: Telemetrické štúdie priniesli množstvo informácií o ohrozených druhoch dravcov, avšak poznatkov o využívaní priestoru bežnými druhmi a o ich disperzii je stále málo. V tejto práci opisujem domovský okrsok a hniezdnu disperziu samca myšiaka hôrneho označeného pomocou GPS vysielača, sledovaného v juhovýchodnom Estónsku v rokoch 2014 - 2016 . Domovský okrsok myšiaka pokrýval 8,3 km² (kernel $95 \%$ odhad), jadrové územie malo 2,1 km² (kernel 50 \%). Domovský okrsok sa v priebehu hniezdnej sezóny zväčšoval, pred migráciou sa ale opätovne zmenšil. Prekvapujúco, hniezda v dvoch po sebe idúcich hniezdnych sezónach boli situované na opačných koncoch domovského okrsku, 1,7km od seba.
\end{abstract}

Key words: dispersal, home range, nesting territory, telemetry, Estonia

Ülo Väli, Department of Zoology, Estonian University of Life Sciences, Kreutzwaldi 5, 51014 Tartu, Estonia. E-mail: ulo.vali@emu.ee.

Acknowledgements: I thank Urmas Sellis, Gunda Lein and Erich Starringer for their help in trapping the buzzard, and Urmas Sellis also helped to collate tracking data. Comments from an anonymous reviewer helped to improve the manuscript. The study was part of the campaign "Estonian bird of the year 2015 - buzzards", financed by the Estonian Environmental Investment Centre.

\section{Introduction}

In recent decades, telemetric studies have provided ample information about space use and dispersal of raptors, but compared to the extensive knowledge on many threatened species (e.g. Ferrer 1993, Balbontin 2005, Pérez-García et al. 2015), still surprisingly little is known about common species (but see e.g. Kenward et al. 2001, Wiens et al. 2006). The common buzzard (Buteo buteo) is the most abundant and widespread of European raptors (Mebs \& Schmidt 2006). Although numerous studies have described its breeding density, not many have analysed the spatial pattern of nests and movements of individuals within their home range. The first spatial studies estimated the size and sketched the borders of the defended nesting territory (Mebs 1964, Weir \& Picozzi 1983), and some estimates were also obtained about surrounding foraging areas (Wendland 1952, Dare 1961, Brüll 1964, Thiollay 1967), which however may sometimes coincide with the nesting territory (Melde 1960, Mebs 1964). Only a few studies have directly measured the home range of the common buzzard by means of radio-telemetry, and these have focused on immature birds (Walls \& Kenward 1995, 2001). Similarly, radio-tracking has revealed some properties of natal dispersal, i.e. movement between hatching and breeding sites (Walls \& Kenward 1995, 1998, Walls et al. 2005), but information on breeding dispersal, i.e. distance between nests of an adult in subsequent years, is virtually lacking (Paradis et al. 1998; but see Kenward et al. 2001).

The common buzzard is the most common bird of prey also in Estonia, north-eastern Europe, where nesting pairs of buzzards are distributed regularly across the landscape with a mean distance of ca. $2 \mathrm{~km}$, while alternative nests of the same pair are usually found within a few hundred meters (Väli 2015). Exceptionally nests 
of two pairs of buzzards have been recorded only 300 meters from each other in Estonia (Randla 1976), and elsewhere the minimum distances have been even less than one hundred meters (Mebs 1964, Hardey et al. 2009). In 2015 buzzards were in the spotlight as birds of the year in Estonia, and GPS-telemetry was used to gather novel information about the species. Data on habitat preferences and migration of tracked Estonian buzzards have previously been published (Väli et al. $2015 a, b)$. In the current study I describe the home range size of a male common buzzard and its rather broad breeding dispersal across the range.

\section{Methods}

On September 7, 2014 an adult male common buzzard was trapped near Aarna village, Põlva county, southeastern Estonia $\left(58.1^{\circ} \mathrm{N}, 26.9^{\circ} \mathrm{E}\right)$, in a recently (2014) established raptor monitoring area. In 2015 and 2016 there were 16 and 17 pairs of common buzzards breed-

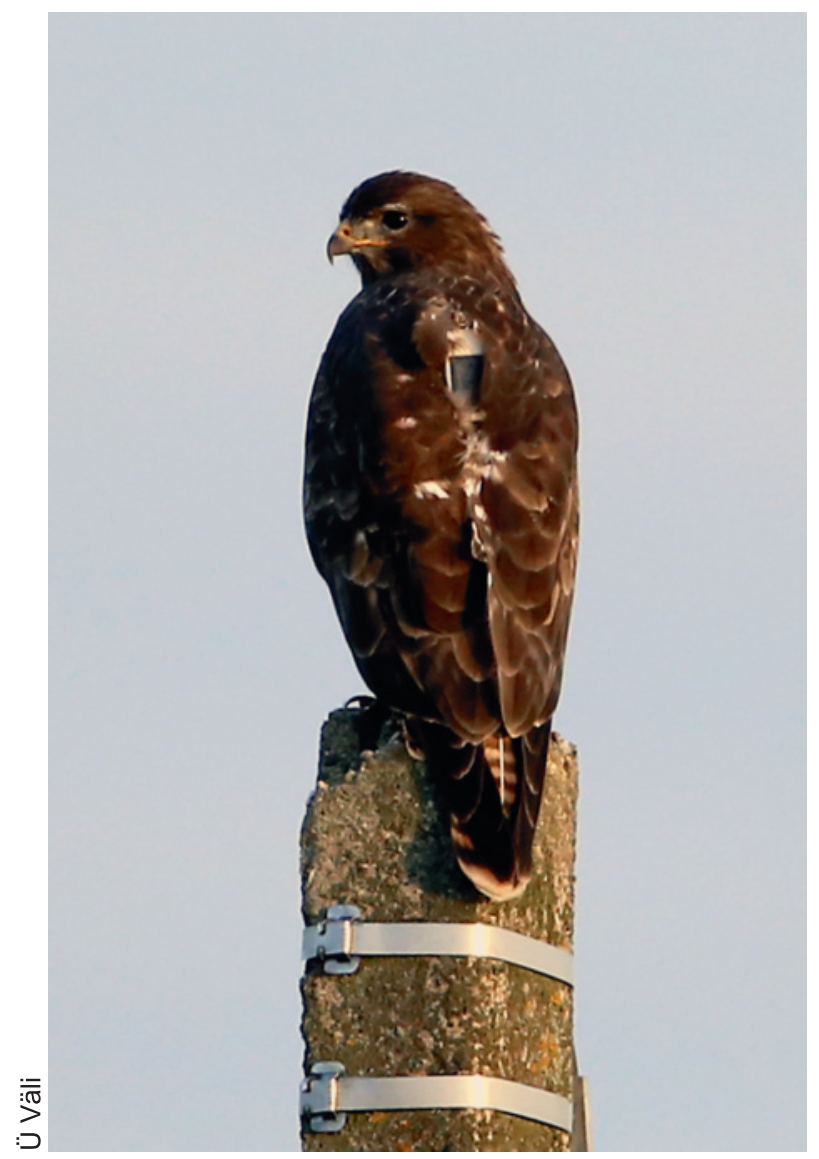

Fig. 1. The GPS-tracked common buzzard.

Obr. 1. Myšiak hôrny s GPS vysielačom. ing in a $50 \mathrm{~km}^{2}$ area, which is the highest breeding density of the species in Estonia recorded thus far. The productivity in these years was 0.80 and 1.34 fledglings per occupied nest respectively, and the mean distance between neighbouring occupied buzzard nests was 1.18 $\mathrm{km}(\mathrm{n}=10)$. Other potential competitors for nests in the study area were the honey buzzard (Pernis apivorus; 2 pairs), goshawk (Accipiter gentilis, also a potential predator; 1-2 pairs) and Ural owl (Strix uralensis; 6 pairs).

For trapping, a decoy stuffed eagle owl and a mistnet were placed in a foraging area and the buzzard was caught while chasing this potential predator away from his fledged young nearby. The bird was marked using a metal ring and a GPS-logger, which recorded four locations a day (28 gram model Sula, Ecotone; Fig. 1). The logger stopped transmissions in mid-winter 2015/16. In spring 2016 the buzzard with the transmitter was detected again in the course of regular monitoring; it was retrapped to verify its identity and to remove the nonfunctioning logger on June 17, 2016 using a decoy stuffed white-tailed eagle and a mist-net, placed some $50 \mathrm{~m}$ from its nest. In order to follow the details of breeding in 2015, the nest of the tracked buzzard was equipped with a trail camera (Trophy Cam 119435, Bushnell).

The size of the home range was estimated using the fixed kernel density method (Worton 1989) with reference bandwidth to calculate the smoothing parameter. Slow increase in home range size until $95 \%$ probability, and steep increase thereafter, suggested kernel $95 \%$ estimate (K95\%) as the most suitable method for estimating the total size of the home range without excursive activity. Comparatively, kernel 50\% (K50\%) was used to describe the core area of the home range. Calculations of home range size were conducted using the adehabitatHR package (Calenge 2006) in the statistical environment $\mathrm{R}$ version 3.2.3 ( $\mathrm{R}$ Development Core Team 2015).

\section{Results}

In autumn 2014 movements of the buzzard in the breeding grounds were followed for nearly four weeks after tagging as it started autumn migration on October 5, 2014. During this period 111 GPS-fixes indicated a home range covering $8.0 \mathrm{~km}^{2}(\mathrm{~K} 95 \%)$ and a core area (K50\%) of $2.1 \mathrm{~km}^{2}$.

The tagged bird returned to its breeding ground on March 24, 2015 and bred $930 \mathrm{~m}$ from the trapping site. The clutch contained a single egg, which was laid in 


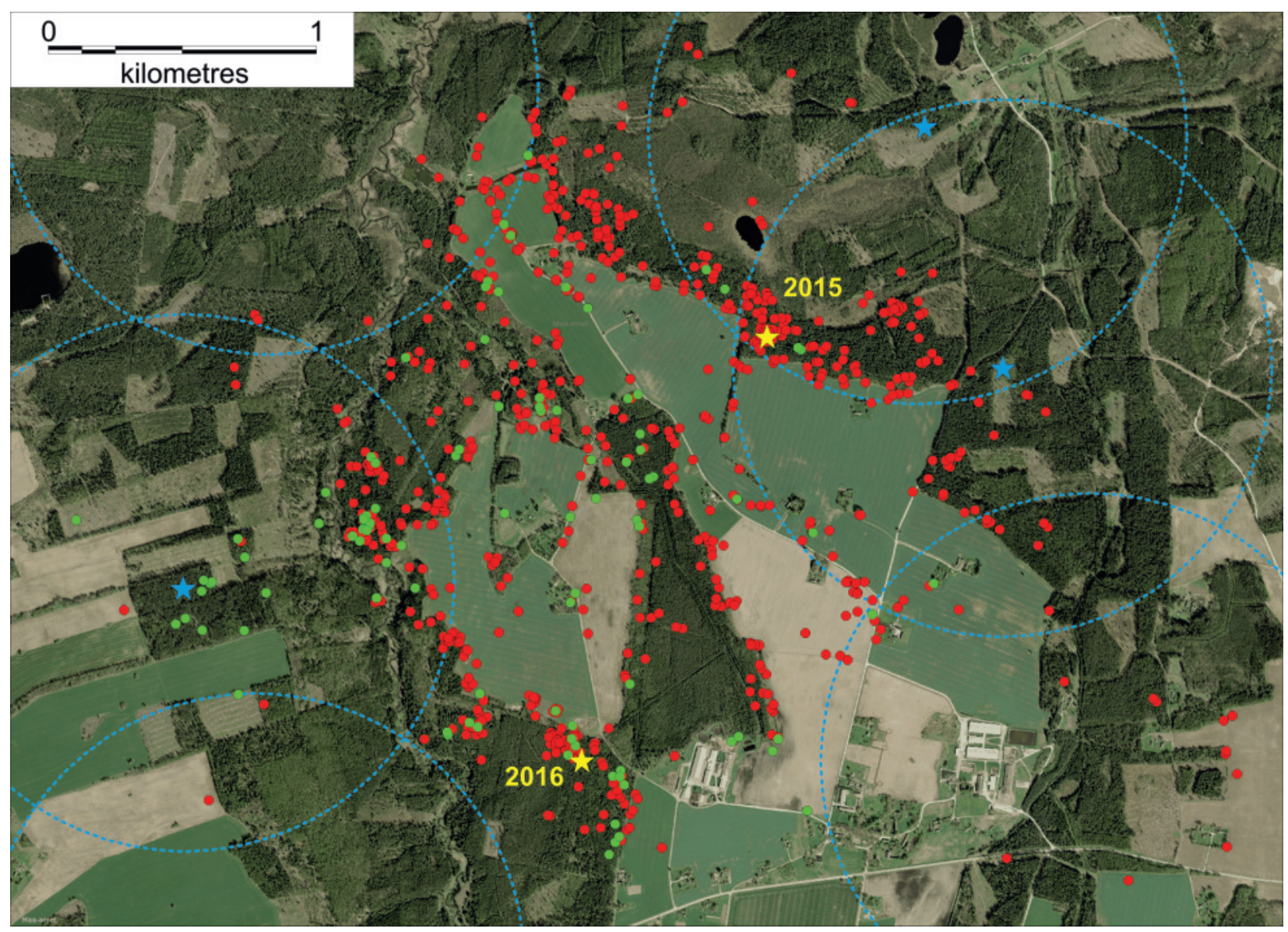

Fig. 2. Registered locations of the studied common buzzard in 2014 (Sept-Oct; green dots) and in 2015 (March - Oct; red dots) and its nests in 2015 and 2016 (yellow stars). Known nests and territories of the neighbouring common buzzards (all occupied both in 2015 and 2016) are indicated as blue stars and circles respectively. Two locations from 2014 and ten from 2015 were further away and are not presented.

Obr. 2. Registrované lokácie študovaného myšiaka hôrneho v 2014 (september - október; zelené body) a v 2015 (marec - október; červené body) a jeho hniezda v 2015 a 2016 (žlté hviezdy). Známe hniezda a teritóriá susedných myšiakov hôrnych (všetky obsadené v 2015 a 2016) sú vyznačené modrými hviezdami a krúžkami. Dve lokácie z 2014 a desat' z 2015 ležia mimo zobrazenú oblast' a preto nie sú prezentované.

April 22; the nestling hatched on May 26 and fledged on July 10 . Until the start of the next autumn migration on October 11, 2015, 787 fixes were obtained (Fig. 2). The home range covered an area of $8.3 \mathrm{~km}^{2}$ (K95\%) south-west from the nest and the core range (K50\%) was again $2.1 \mathrm{~km}^{2}$. The home range increased in the course of the breeding season but decreased again before migration (Tab. 1). These temporal changes in size of the core range and the total range were synchronous.

In spring 2016 the nest of the previous year was decorated again by buzzards using green sprays, but eggs were not laid and the identity of the occupying birds was not known. However, in June 2016 the buz- zard with the GPS-logger was seen carrying food to another nest, located $1.7 \mathrm{~km}$ from the one used for breeding in 2015. Again, the nest contained a nestling and this enabled us to trap the adult. The ID-numbers of the ring and the GPS-logger confirmed that the bird was the individual trapped by us in 2014. The new nest was situated on the south-western margin of the home range of 2015. Recorded coordinates revealed that the buzzard had already visited this nest in 2015 , and moreover the movements in autumn 2014 were close to this nest. According to visual observations in 2016, the marked buzzard was using the same home range as in 2015. 
Tab. 1. Temporal changes in home range size of the GPStracked common buzzard $\left(\mathrm{km}^{2}\right)$. Core ranges as kernel $50 \%$ (K50\%) and total ranges as kernel 95\% (K95\%) are presented.

Tab. 1. Časové zmeny vel'kosti domovského okrsku myšiaka hôrneho sledovaného pomocou GPS $\left(\mathrm{km}^{2}\right)$. Jadrová zóna zobrazená ako 50\%-ný kernel (K50\%) a celý okrsok ako 95\%-ný kernel (K95\%).

\begin{tabular}{llc}
\hline & K50\% & K95\% \\
\hline September 2014 & 1.77 & 7.37 \\
April 2015 & 1.47 & 6.15 \\
May 2015 & 1.62 & 5.88 \\
June 2015 & 2.40 & 8.48 \\
July 2015 & 2.07 & 7.48 \\
August 2015 & 3.67 & 16.77 \\
September 2015 & 1.32 & 5.92 \\
\hline
\end{tabular}

\section{Discussion}

Observational studies have suggested that foraging flights of the common buzzard are distributed over 4-12 km² (Dare 1961, Brüll 1964, Thiollay 1967). These estimates corroborate the home range size measured in the current study, as well as the similar results obtained from the two buzzards GPS-tracked in Estonia for shorter periods (Väli et al. 2015a). Other studies in central Europe and the British Isles have suggested smaller home ranges (Melde 1960, Mebs 1964, Walls \& Kenward 2001), which may be true considering the higher proportion of foraging habitats and prey densities there. Indeed, although the tracked Estonian buzzard foraged mostly in various open habitats such as mowed grasslands, oilseed rape fields and cereal fields, many daytime fixes were also registered in forest areas (Väli et al 2015a). The size of the main prey may also play a role: in Britain for example buzzards have been found feeding mainly upon European rabbits (Oryctolagus cuniculus; Newton 1979), while trail camera photographs and analysis of pellets collected at the nest revealed that the offspring of the Estonian tracked bird had a rather diverse diet consisting mostly of voles (Microtus spp.) or other rodents and moles (Talpa europaea), and less of amphibians and birds (Väli et al. 2015a). Similarly to other raptors (Newton 1979), the home range of the tracked male buzzard was small during incubation time and increased after hatching of the young. It made its longest flights after fledging of the offspring, but before migration the range diminished again.

Both natal and breeding dispersal distances are shortest among abundant species and among species with largest geographical ranges (Paradis et al. 1998). Therefore, short breeding dispersal distances are expec- ted in the case of the abundant and widespread common buzzard. Indeed, among twelve breeding radio-tracked buzzards in Britain, eleven moved less than $1 \mathrm{~km}$ and only one individual, in an area of low density of buzzards, moved to breed $1.92 \mathrm{~km}$ away from the previous pairing site (Kenward et al. 2001). Therefore it was surprising to see the only studied bird moving as much as $1.7 \mathrm{~km}$, especially as the area was densely inhabited by buzzards and the neighbouring pairs were breeding less than $1 \mathrm{~km}$ away. Moreover, there were several other suitable options available much closer (Fig. 2). No forestry activity was recorded, which would have forced birds to move (Kontkanen et al. 2004, but see Lõhmus 2005), and in general the agricultural use of the open landscape, which shapes the foraging conditions of the common buzzard (Melde 1960, Mebs 1964, Krüger 2002, Lõhmus 2003), was similar in both years. Forestdwelling raptors are known for their high site-fidelity and they often use the same nests in consecutive years, especially after successful breeding (Newton 1979). Therefore, it is even harder to explain the long dispersal event after successful breeding described here. The case described here clearly highlights the need for further studies in order to make conclusions on drivers of breeding dispersal.

Common buzzards may seldom exchange nesting territories (Krüger 2002). Whether this happened here actually depends on the definition of nesting territory. If it is defined as an area containing one or more nests within the home range of a mated pair (Steenhof \& Newton 2007), then the studied case consists only of a movement inside a large nesting territory. However, this conclusion is not so obvious if the extension of this definition is followed: a nesting territory is a confined locality where nests are found, usually in successive years, and where no more than one pair is known to have bred at one time (Steenhof \& Newton 2007). Finally, if nesting territory is defined as an area defended from conspecifics and predators (Hardey et al. 2009), the case studied here is undoubtedly a movement between different nesting territories, as buzzards defend only a restricted area around their nest $\left(0.5-1 \mathrm{~km}^{2}\right.$; Walls \& Kenward 2001, Hardey et al. 2009). Whatever the conclusion about the nesting territory, GPS-tracking indicated that the dispersal studied here did not extend beyond the boundaries of the home range, but was just a movement from one margin to another within it. Without the GPS-logger and ring recovery the two nests of the buzzard would have been undoubtedly considered as belonging to separate breeding pairs. 


\section{References}

Balbontín J 2005: Identifying suitable habitat for dispersal in Bonelli's eagle: an important issue in halting its decline in Europe. Biological Conservation 126: 74-83. DOI: 10.1016/j.biocon.2005.04.023.

Brüll H 1964: Das Leben deutscher Greifvögel: ihre Bedeutung in der Landschaft. Neumann-Neudamm, Stuttgart.

Calenge C 2006: The package adehabitat for the R software: a tool for the analysis of space and habitat use by animals. Ecological Modelling 197: 516-519. DOI: 10.1016/j.ecolmodel.2006.03.017.

Dare P 1961: Ecological observations on a breeding population of the common buzzard (Buteo buteo). $\mathrm{PhD}$ thesis, Exeter University.

Ferrer M 1993: Juvenile dispersal behaviour and natal philopatry of a long-lived raptor, the Spanish imperial eagle Aquila adalberti. Ibis 135: 132-138.

Hardey J, Crick H, Wernham C, Riley H, Etheridge B \& Thompson D 2009: Raptors: a field guide for surveys and monitoring. Second edition. The Stationery Office, Edinburgh, 311.

Kenward RE, Walls SS \& Hodder KH 2001: Life path analysis: scaling indicates priming effects of social and habitat factors on dispersal distances. Journal of Animal Ecology 70: 1-13.

Kontkanen H, Nevalainen T \& Lõhmus A 2004: Röövlinnud ja metsamajandus [Birds of prey and forestry]. Eesti Entsüklopeediakirjastus, Tallinn, 92. [in Estonian]

Kotkaklubi \& 5DVision 2017: Birdmap. Retrieved January 21, 2017 from http://birdmap.5dvision.ee.

Krüger O 2002: Dissecting common buzzard lifespan and lifetime reproductive success: the relative importance of food, competition, weather, habitat and individual attributes. Oecologia 133: 474-482.

Lõhmus A 2003: Are certain habitats better every year? A review and a case study on birds of prey. Ecography 26: 545-552. DOI: $10.1034 / \mathrm{j} .1600-$ 0587.1999.03575.x.

Lõhmus A 2005. Are timber harvesting and conservation of nest sites of forest-dwelling raptors always mutually exclusive? Animal Conservation 8: 443-450. DOI: 10.1017/S1367943005002349

Mebs Th 1964: Zur Biologie und Populationsdynamik des Mäusebussards (Buteo buteo). Journal für Ornithologie 105: 247-306.

Mebs Th \& Schmidt D 2006: Die Greifvögel Europas, Nordafrikas und Vorderasiens. Kosmos, Stuttgart, 496.
Melde M 1960: Das Revier des Mäusebussards. Falke 7 : 100-105.

Newton I 1979: Population ecology of raptors. Poyser, Berkhamsted, 399.

Paradis E, Baillie SR, Sutherland WJ \& Gregory RD 1998: Patterns of natal and breeding dispersal in birds. Journal of Animal Ecology 67: 518-536.

Pérez-García JM, Sellis U \& Väli Ü 2014. Winter ranging behaviour of a greater spotted eagle (Aquila clanga) in southeast Spain during four consecutive years. Slovak Raptor Journal 8(2): 123-128. DOI: 10.2478/srj-2014-0014.

R Development Core Team 2015: R: A language and environment for statistical computing. R Foundation for Statistical Computing, Vienna, Austria, http://www.R-project.org/

Randla T 1976: Eesti röövlinnud [Estonian birds of prey]. Valgus, Tallinn, 200. [In Estonian with English summary]

Steenhof K \& Newton I 2007: Assessing nesting success and productivity, 181-192. In: Bird DM \& Bildstein $\mathrm{K}$ (eds) Raptor research and management techniques. Hancock House Publishers, Surrey, 463.

Thiollay JM 1967: Ecologie d'une population de rapaces diurnes en Lorraine. Terre Vie 2: 116-183.

Väli Ü 2015: Hiireviu - viiuldaja taevavõlvil. [The common buzzard - fiddler in the sky]. Eesti Loodus 66: 136-141. [in Estonian]

Väli Ü, Sein G, Laansalu A \& Sellis U 2015a: Milliseid elupaiku eelistavad meie viud? [Which habitats prefer our buzzards?] Eesti Loodus 66: 636-640. [In Estonian]

Väli Ü, Sellis U \& Vainu O 2015b: Kuhu lendavad meie viud? [Where do our buzzards fly?] Eesti Loodus 66: 703-709. [In Estonian]

Walls SS \& Kenward RE 1995: Movements of radiotagged common buzzards Buteo buteo in their first year. Ibis 137: 177-182.

Walls SS \& Kenward RE 1998: Movements of radiotagged buzzards Buteo buteo in early life. Ibis 140 : 561-568.

Walls SS \& Kenward RE 2001: Spatial consequences of relatedness and age in buzzards. Animal Behaviour 61: 1069-1078.

Walls SS, Kenward RE \& Holloway GJ 2005: Weather to disperse? Evidence that climatic conditions influence vertebrate dispersal. Journal of Animal Ecology 74: 190-197.

Weir DN \& Picozzi N 1983: Dispersion of buzzards in Speyside. British Birds 76: 66-78. 
Wendland V 1952: Populationsstudien ab Raubvögeln. Journal für Ornithologie 93: 144-153.

Wiens DJ, Reynolds RT \& Noon BR 2006: Juvenile movement and natal dispersal of northern goshawks in Arizona. The Condor 108: 253-269.

Worton B 1989: Kernel methods for estimating the utilization distribution in home-range studies. Ecology 70: 164-168. 